\title{
Paweł Kumor
}

University of Lodz

Faculty of Economics and Sociology

e-mail: kumor@uni.lodz.pl

\section{Is there a growing social acceptance of earnings inequalities in Poland?*}

\begin{abstract}
In our studies, we deal with the estimating of the optimal ranges of earnings - the optimal Gini indexes which are favourable to the maximisation of GDP growth in Poland. We suspect that the optimal Gini coefficients expressing the whole of society's acceptance of earnings inequalities can increase.

In the article, we formulated a hypothesis on society's habituation to increasing earnings disparities. We verified the hypothesis on the basis of the model of economic growth using data from 1970 to 2007 . We carried out econometric studies in two stages. In the first stage, we estimated the optimal Gini coefficients for short subsequent sub-periods. In the second stage, we studied the character of changes in the optimal Gini coefficients.

In the studies, we proved the hypothesis on society's habituation to increasing earnings disparities. The optimal Gini coefficients increase along with the increase of differences in earnings and the increase of the economic level per capita. The growth of the optimal Gini coefficients may be slowed down.
\end{abstract}

Keywords: social acceptance, earnings, inequalities, econometric model, Poland

JEL Classification: D6

\footnotetext{
* I would like to thank Professor J. Jacek Sztaudynger, and the participants of his doctoral seminar for the remarks which they contributed to the article. The text was prepared as part of the supervisor's research grant: Income Inequalities and Economic Growth 2773/B/H03/2008/35, financed from research funds in the years 2008-2010. The article is an updated version of the paper published in Polish in the Annales. Ethics in Economic Life, 14(1), 171-179.
} 


\section{Introduction}

In previous studies (Chen, 2003; Kumor \& Sztaudynger, 2007), the parabolic effect of earnings (income) inequalities on economic growth was confirmed. On the basis of those studies, optimal earnings inequalities were determined-the optimal Gini coefficients at which economic growth was maximised. Optimal earnings differentiation is thus identified with the disparity which is the most socially acceptable and socially just in the utilitarian approach.

The studies assumed the stability of the optimal value of income (earnings) differentiation. According to this assumption, the optimal value of this disparity did not change over time. The sense of social justice, determined by the optimal Gini coefficient, was the same throughout the entire period considered.

Now, we reject this assumption. We assume that the optimal Gini coefficient may increase with growing earnings differences. The increase in the optimal Gini coefficient may result from the effect of the gradual habituation of the whole of society to growing earnings inequalities. ${ }^{1}$ If, in the coming years, earnings differentiation increases, the optimal Gini coefficients will grow as well. The effect of society's habituation to growing earnings inequalities may result from the gradual enrichment of society. An increase in production per capita improves the living conditions of society and creates more opportunities for its development.

We put forward the hypothesis on society's gradual habituation to growing earnings differentiation. ${ }^{2}$ Social acceptance of increasing earnings inequalities can be seen on the basis of observations in sub-periods.

We will verify the hypothesis concerning society's habituation to increasing earnings differentiation using the economic growth model in which the GDP growth rate will be explained by an increase in the investment rate, the employment growth rate and the parabolic function of earnings inequalities. The analysis will include observations from the years 1971-2007. The research period will be divided into several years of non-separable sub-periods. Estimates of optimal earnings differentiation will be carried out on the basis of each sub-period separately. In the research, we will use the method of least squares.

We assume that the optimal Gini coefficient will grow increasingly slowly as earnings inequalities grow. Then a growing number of lower and middle-income people will protest against excessive differences in earnings. We will attempt to investigate the nature (slowdown) of the increase in the optimal Gini coefficient. At this point, we put forward the second hypothesis that the increase in the optimal Gini coefficient will be slower and bounded from above. To verify this hy-

\footnotetext{
${ }^{1}$ In the years 1970-2006 in Poland, the Gini coefficients (GINI) ranged from $20 \%$ to 35\%. Since 1990 , there has been systematic growth. In 2006, the Gini coefficient increased by approx. 2/3 in relation to the 1989 value (cf. Kumor, 2009).

${ }^{2}$ The hypothesis proposed by J. J. Sztaudynger.
} 
pothesis, we will use in the research a nonlinear function with a horizontal asymptote. Bounding the growth of the optimal Gini coefficient will allow us to set the social acceptance threshold for earnings inequalities.

In the studies of the bounded growth of the optimal Gini coefficient, we will use a model in which the variability of the optimal Gini coefficient will be explained by the variability of GDP per capita.

\section{Theoretical foundations}

Too large and too small differences in earnings are harmful to the economy. Optimal earnings (or income) differentiation favours the building of social bonds that characterise the best interpersonal relationships and the optimal allocation of production factor resources. Earnings inequalities are optimal for economic growth when they allow for the maximisation of GDP growth.

Earnings (income) inequalities constitute the basis of comparisons between people. There are also other areas of comparison, based on, among others, property, personal happiness, the degree of satisfaction of one's needs, freedom, power, or legal and political treatment (cf. Kot, 2004). A diversified level of satisfaction of these categories in society is important in terms of shaping income inequalities and vice versa; income (earnings) inequalities have an impact on the diversified satisfaction of other human needs. There is a correlation between the possibilities of fulfilling various social needs. Ensuring distributive justice, that is, reaching a compromise in one area of comparisons between people, must involve the simultaneous recognition of inequalities (or equalities) in other areas as being just. Hence, "[...] equality of opportunities may be accompanied by a significant degree of income disparities [...]” (pp. 49, 53).

Does social acceptance of earnings inequalities (identified with the optimal Gini coefficient) remain unchanged in time? We suspect that it is not the case. The optimal Gini coefficients may increase with growing earnings inequalities or an increase in national wealth (e.g., GDP level) per capita. This effect may result from society becoming accustomed to increasing earnings differentiation (cf. Cornia \& Court, 2001, p. 22) or from the formation of the political system that strengthens the structure of the economy based on the motivational function of earnings (cf. Baumol, 2007, pp. 545-548).

Furkiss stated that income (earnings) inequalities tend to be "self-sustaining". Thus, as noted by Amartya K. Sen (2000), many "victims of long-standing failures and deprivation [...] do not consider radical change." People become reconciled with their own fate "taking pleasure in small mercies [...]" (p. 20).

The change in the optimal Gini coefficient (its increase) might have been caused by the process of gradual personnel replacement and the introduction of innovations in the field of human resources management initiated in the 1990s. Personnel changes in senior and middle-level management positions, aimed at em- 
ploying people who are better qualified and prepared for the current needs of enterprises, were forced by growing market competition. Enterprises that did not manage to do this lost their position in the market and sometimes even the possibility of conducting further business activity. With the increase in the general level of competence of the senior staff, income (earnings) inequalities grew, and social acceptance increased gradually for better remuneration of the management. Employees could identify their own well-being (including, among others, job security or higher earnings) with the special skills and high competencies of their employers. ${ }^{3}$

To study this phenomenon, we will divide the research period, which covers the years 1971-2007, into several sub-periods which will be analysed separately. Due to the relatively short research period (37 years), the above-presented procedure is difficult to perform. To estimate econometric models, time series of at least a dozen years are needed. Therefore, the tests can be carried out on the basis of subperiods whose time intervals overlap. An example of verifying the hypothesis concerning society's habituation to growing earnings inequalities is presented in Fig. 1.

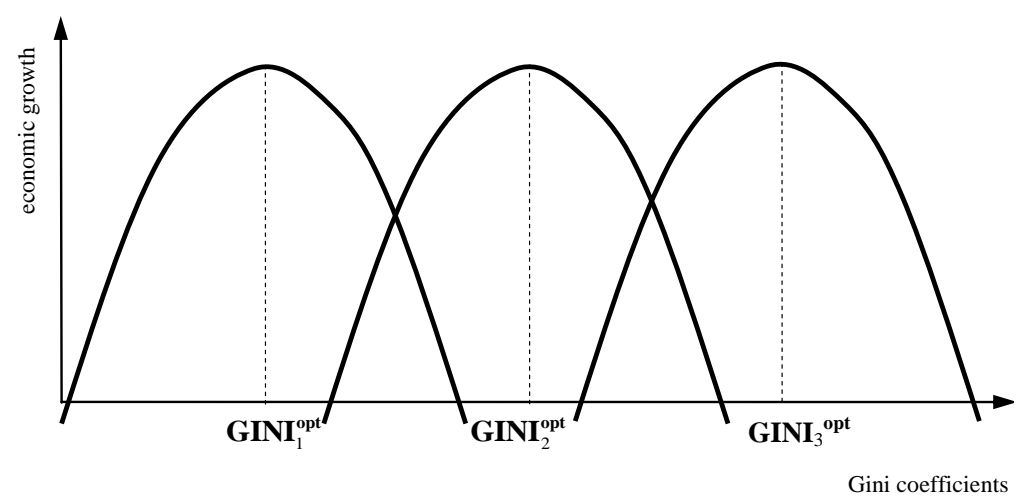

Figure 1. The effect of society's habituation to changes in earnings inequalities

In Figure 1, three parabolas represent the dependence of GDP growth on earnings inequalities. These dependencies are presented in non-separable subperiods for which the optimal Gini coefficients were determined separately. These coefficients will be estimated on the basis of rolling sub-periods (rolling regression), e.g., 18-year-olds: 1971-1988, 1972-1989, etc. For the subsequent subperiod moved in time (e.g., by 1 year, with a fixed number of years), the optimal Gini coefficient increases. The parabolas then move to the right along the horizontal axis.

It is worth asking the following questions: if the changes of the optimal Gini coefficient along with the moving of the sub-period in time are continuous, is there any boundary for these changes? To what value can the optimal Gini coeffi-

\footnotetext{
${ }^{3}$ As indicated, for example, by Boni (cf. Kowalik, 1997, p. 302). Salaries of employees and employers (fully-employed persons) are used in CSO representative surveys to calculate Gini coefficients of earnings inequalities (more on the subject in Kumor, 2006).
} 
cient increase $?^{4}$ We assume that the increase in the optimal coefficient in the subsequent years (along with the increase in the earnings spread over time, and the economic level per capita) may decrease, until the full potential of the earnings (income) motivational function is fulfilled and the social effect of the sense of exploitation prevails. Social acceptance of growing earnings inequalities will practically cease to increase as a result of stabilisation during a fair distribution of earnings (the optimal Gini coefficient) and a fair distribution of other goods (e.g., property, the degree of satisfaction of needs, freedom, legal and political treatment) mentioned earlier.

Figure 2 shows a gradual increase in the optimal Gini coefficient. The increase in the optimal Gini coefficient, plotted with a concave function, decreases with the upper bound determined by a horizontal asymptote. This means that for the subsequent sub-periods, the optimal Gini coefficients will approach the threshold of social acceptance of growing earnings differentiation.

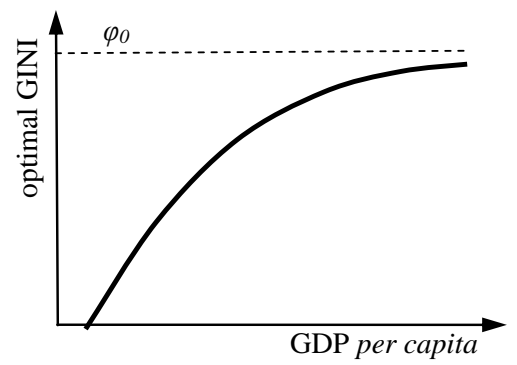

Figure 2. Dependence of the optimal Gini coefficient on the level of GDP per capita Note. GINIopt $=\varphi_{0}-$ horizontal asymptote; GINIopt - optimal values of the Gini coefficient, \% (vertical axis).

\section{Analysis of the effect of growing social acceptance of earnings inequalities}

In econometric studies, we will use a modified economic growth model (1) based on the model proposed by Kumor and Sztaudynger (2007). The modification consists, among others, in removing the investment rate from the list of explanatory

$$
\boldsymbol{G} \dot{\boldsymbol{D} P}=\alpha_{0}+\alpha_{1} \dot{\boldsymbol{L}}+\alpha_{2} \Delta\left(\frac{\boldsymbol{I}}{\boldsymbol{G D P}}\right)_{-1}+\alpha_{3} \boldsymbol{G I N I _ { - 1 }}+\alpha_{4} \boldsymbol{G I N I _ { - 1 } ^ { 2 }}+\alpha_{5} \boldsymbol{u} 8081
$$

variables due to the most frequently received wrong sign and the insignificance of variables in our research. Instead of the investment rate, its increase was introduced into the GDP growth model.

\footnotetext{
${ }^{4}$ We are asking about it being bounded below, based on the definition of the Gini coefficient, i.e. $100 \%$.
} 
where:

$\boldsymbol{G} \dot{\boldsymbol{D} P}$ GDP growth rate in constant prices, \%,

$\dot{\boldsymbol{L}}$ employment growth rate, \%,

I/GDP investment rate (investment - GDP ratio in current prices), $\%, \Delta$-variable increment,

GINI Gini coefficient, \%.

u8081 dummy variable, separating the years 1980-1981,

$\alpha_{i} \quad$ model structural parameters, where $i \in\{0,1, \ldots, 5\}$

$\varepsilon \quad$ random component.

The entire research period (1971-2007) was divided into sub-periods of several years. Econometric research was carried out on the basis of observations from short sub-periods overlapping by 1 year. Correct signs of parameter estimates or the largest values of Student's t-statistic of parameter estimates at variables were obtained for 18-year sub-periods. Estimates for the remaining analysed variants, 15, 19, 22 and 25-years, were rejected.

The results of the ordinary least squares method (OLS) are presented in Table 1.

Table 1. Optimal Gini coefficients

\begin{tabular}{|c|c|c|c|c|c|}
\hline No. & Years & $\mathrm{GINI}_{\mathrm{opt}}$ & No. & Years & $\mathrm{GINI}_{\mathrm{opt}}$ \\
\hline 1. & 1970-1987 & 22.5 & 11. & 1980-1997 & 26.2 \\
\hline 2. & 1971-1988 & 22.6 & 12. & 1981-1998 & 27.7 \\
\hline 3. & 1972-1989 & 22.7 & 13. & 1982-1999 & 29.1 \\
\hline 4. & 1973-1990 & 23.2 & 14. & $1983-2000$ & 27.1 \\
\hline 5. & 1974-1991 & 23.4 & 15. & 1984-2001 & 27.2 \\
\hline 6. & 1975-1992 & 24.2 & 16. & 1985-2002 & 28.0 \\
\hline 7. & 1976-1993 & 24.5 & 17. & 1986-2003 & 28.7 \\
\hline 8. & 1977-1994 & 25.6 & 18. & 1987-2004 & 28.6 \\
\hline 9. & 1978-1995 & 25.5 & 19. & 1988-2005 & 29.2 \\
\hline 10. & 1979-1996 & 25.5 & 20. & 1989-2006 & 29.5 \\
\hline
\end{tabular}

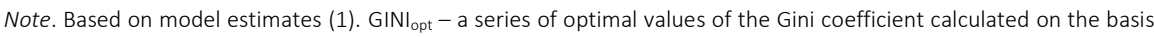
of the results of estimation using the least squares model (1), \%; the highest level of significance (corresponding to the smallest value of Student's t-statistic) of the parameter estimates at the Gini coefficient squared to the power of one and two was marked with asterisks, ${ }^{* *}: 1 \%,{ }^{* *}: 5 \%,{ }^{*}: 10 \%$.

Table 1 presents a series of 20 optimal values of the Gini coefficient. The optimal Gini coefficients were ordered into the sub-periods including the 1-year lag of Gini coefficients in model (1). For example, if earnings inequalities in 1987 were equal to the optimal Gini coefficient (22.5\%), economic growth in 1988 would be maximised.

Only some of the optimal values of the Gini coefficient are precisely estimated. This is indicated by the significance levels (marked by asterisks in Table 1) of parameter estimates with the Gini coefficients estimated on the basis of model (1). The highest $t$ statistics (i.e. no more than $10 \%$ of the significance levels) for pa- 
rameter estimates characterising the impact of earnings inequalities on GDP growth were obtained for the last eight sub-periods, i.e. the years 1982-1999, 1983-2000, ..., 1989-2006.

The results are presented below.

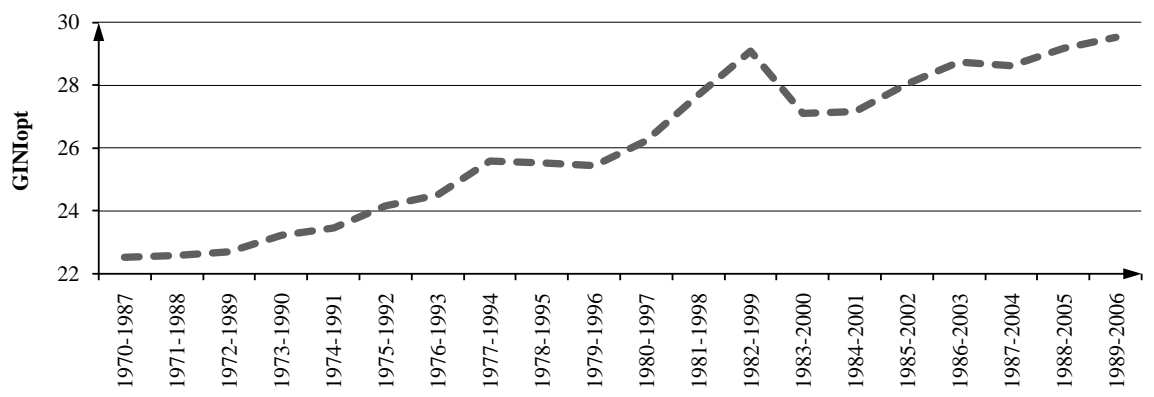

Figure 3. Optimal values of the Gini coefficient

Note. Based on Table 1. GINlopt-optimal Gini coefficient, \%.

Fig. 3 presents a series of the optimal Gini coefficients. It is characterised by an upward trend. The lowest value, 22.5\%, was obtained in the years 1970-1987. The highest, $29.5 \%$, was obtained in the years 1989-2006. The optimal values of the Gini coefficient increased by 7 percentage points.

\section{Analysis of the variability of optimal values of the Gini coefficient}

In the next step of the analysis, we will examine the non-linear influence of the level of GDP per capita on shaping the optimal values of the Gini coefficient. This dependence can be mapped using the shape of the curve shown in Fig. 2. To verify the hypothesis concerning the increasingly slow growth of the optimal value of the Gini coefficient, we will use a model with a nonlinear function with a horizontal asymptote:

$$
\text { GINIopt }=\varphi_{0}+\varphi_{1} \frac{1}{\text { GDPpc }_{-1}}+\varepsilon ; \quad \varphi_{0}>0, \text { GDPpc } \geq\left(-\frac{\varphi_{1}}{\varphi_{0}}\right)
$$

where:

GINIopt a series of optimal values of the Gini coefficient (from 0), \%,

GDPpc GDP per capita (2007 constant prices, PLN),

$\varphi_{0}, \varphi_{1} \quad$ model parameters,

$\varepsilon \quad$ random component. 
In order to continue our research, we assigned the optimal values of the Gini coefficients (from Table 1) to the penultimate year from each sub-period. ${ }^{5}$ The optimal value of the Gini coefficient (in Table 1) from the first subperiod (the years 1970-1987): 22.5\%, was assigned to 1986, from the second sub-period (the years 1971-1988): 22.6\%-1987, etc.

In our opinion, the penultimate year of the sub-period is the most representative one. Social acceptance of earnings inequalities results then from the past and current feelings of people. It is connected with people "remembering" better the latest experiences related to, among others, earnings differentiation.

The results of model (2) estimates carried out by means of the MNK method are presented below (for years 1992-2005).

$$
\begin{gathered}
\text { GINIopt }=35.0-151.8 \frac{1}{\boldsymbol{G D P p}_{-1}} \\
\boldsymbol{R}^{2}=0.834 \quad \boldsymbol{D} W=1.64
\end{gathered}
$$

Parameter estimates have signs consistent with the postulated ones.

Based on model (2) in Fig. 4, a curve convergent to the horizontal asymptote was drawn. The intersection of the horizontal asymptote $\varphi_{0}$ with the ordinate (vertical) axis is determined by the estimate of the parameter at the absolute term, $35 \%$. The value of $35 \%$ means the upper bound of growth of the optimal value of the Gini coefficient was caused by the increase in the level of GDP per capita. In Fig. 4, the optimal values of the Gini coefficient corresponding to the level of GDP per capita (from the previous year) are marked with rhombuses $(\diamond)$.

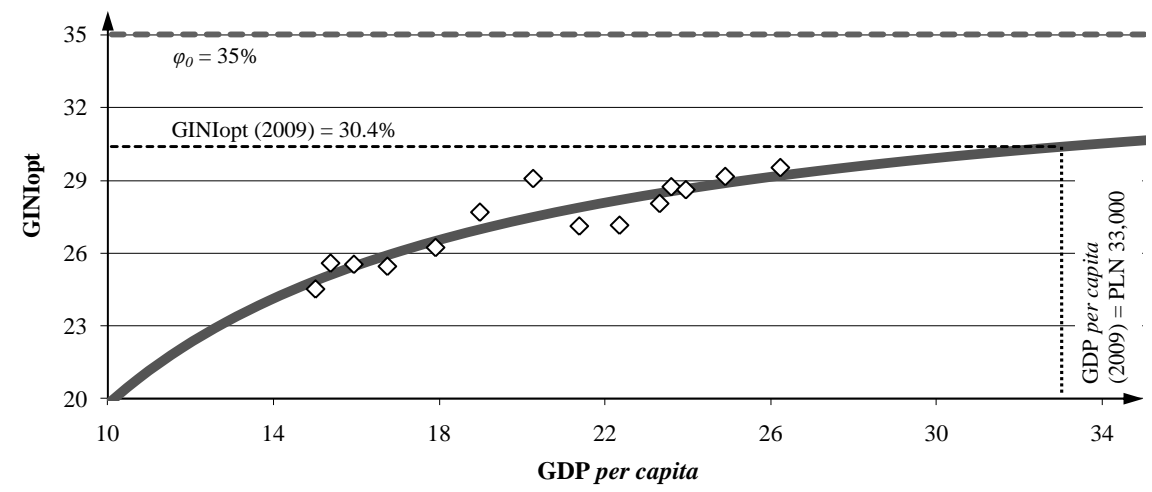

Figure 4. The curve characterising the non-linear dependence between the optimal values of the Gini coefficient and GDP per capita

Note. Based on model (2)'where GINlopt $=\varphi_{0}$ - horizontal asymptote; GINI opt - optimal Gini coefficient, \%; GDP per capita - level of GDP per capita (in constant 2007 prices, PLN).

\footnotetext{
${ }^{5}$ This assigning was done on the basis of the best results of multivariate analysis.
} 
The research results of model (2) presented in Fig. 4 allow us to confirm the positive impact of GDP per capita on optimal earnings differentiation. The increase in the optimal values of the Gini coefficient gets increasingly smaller in relation to the level of GDP per capita.

The Gini coefficient, $\varphi_{0}=35 \%$, can set the social acceptance threshold for an increase in earnings differentiation (in infinity). As mentioned earlier, for 2005, the optimal value of the Gini coefficient was set at 29.5\% (from the 1989-2006 sub-period in Table 1). The difference between the values of the Gini coefficient: maximum, $\varphi_{0}=35 \%$, and optimal, $29.5 \%$, is 5.5 percentage points. This difference means that in the following years, with the increase of GDP per capita, the optimal values of the Gini coefficient will grow. For example, if GDP per capita grows by 1.1 thousand PLN per year (as in the last 10 years on average), according to model (2), the optimal value of the Gini coefficient will exceed $30 \%$ in 2009 . Over the next 30 years, the optimal Gini coefficients could reach $30.5 \%$ in $2010,31.6 \%$ in $2020,32.3 \%$ in 2030 , and $32.7 \%$ in 2040 , ceteris paribus.

\section{Conclusions}

In the light of the results obtained, the hypothesis concerning society's habituation to growing earnings differentiation has been confirmed. The optimal Gini coefficients increase with an increase in differences in earnings and an increase in the economic level per capita. This means that acceptance of earnings inequalities is growing in society.

Based on our model, we have set the bound of this growth. The growth of the optimal Gini coefficient is decreasing and convergent asymptotically to $35 \%$. In our opinion, the $35 \%$ Gini coefficient defines the long-term social acceptance threshold for an increase in earnings inequalities. In subsequent years in which the level of GDP per capita grows, social acceptance of growing earnings differentiation will become increasingly smaller.

\section{References}

Baumol, W. J. (2007). On income distribution and growth. Journal of Policy Modeling, 29(4), 545-548.

Chen, B.-L. (2003). An inverted-U relationship between inequality and long-run growth. Economics Letters, 78, 205-212.

Cornia, G. A., \& Court, J. (2001). Inequality, growth and poverty in the era of liberalization and globalization. Helsinki: The United Nations University WIDER. http:// www.wider.unu.edu/publications/pb4

Kołodko, G. W. (2008). Wędrujący świat. Warszawa: Prószyński i S-ka. 
Kot, S. M. (2004). Nierówności ekonomiczne i społeczne a zasady sprawiedliwości dystrybutywnej. Nierówności Społeczne a Wzrost Gospodarczy, 4, 45-55.

Kowalik, T. (1997). Czy sprawiedliwość społeczna kosztuje? Artykuł polemiczny na marginesie książki pt. Efektywność a sprawiedliwość. Ekonomista, 3, 291-323.

Kumor, P. (2006). Nierównomierność rozkładu płac. Wiadomości Statystyczne, 9, 1-12.

Kumor, P. (2009). Współzależność nierówności płac ze wzrostem gospodarczym w Polsce. Wiadomości Statystyczne, 7, 10-28.

Kumor, P. (2011). Czy w Polsce rośnie akceptacja społeczna dla nierówności płac? Annales. Ethics in Economic Life, 14(1), 171-179.

Kumor, P., \& Sztaudynger, J. J. (2007). Optymalne zróżnicowanie płac w Polsce - analiza ekonometryczna. Ekonomista, 1, 45-59.

Sen, A. (2000). Nierówności. Dalsze rozważania (J. Topińska, Trans.). Kraków: Wydawnictwo Znak. 